\title{
WHAT KIND OF CHANGES ARE THERE IN THE ENTREPRENEURIAL SPIRIT OF THE UNIVERSITY STUDENTS IN THE SOUTH OF THE STATE OF MEXICO?
}

\author{
JAVIER JESÚS RAMÍREZ HERNÁNDEZ \\ Universidad Autónoma del Estado de México, Tenancingo \\ México \\ jjramirezh@uaemex.mx \\ ERANDI TENA LUIS \\ Universidad Autónoma del Estado de México, Tenancingo \\ México \\ JESSICA ALEJANDRA AVITIA RODRÍGUEZ \\ Universidad Autónoma del Estado de México, Tenancingo \\ México
}

\begin{abstract}
Economies worldwide, Mexican included, have the need to face unemployment and offer new jobs, due to this fact, it is fomented the creation of employment through diverse routes, one of them is pathway entrepreneur. The purpose of this working paper is to determine the entrepreneur features among students of Bachelor of the UAEM Tenancingo University Center, in a municipality in the south of State of Mexico, Mexico. Method used is the given by Ramírez (2010), as it allows to establish the presence of inherent elements of entrepreneur and its environment. They responds to a series of different elements such as values, abilities, attitudes, ideals, familiar environment, among others. The compilation of information is done by a survey applied to a student's sample so in that way remark the most relevant qualities. According to results, nowadays, the most relevant features are kindness and tenacity, minor quantity of features in contrast to the past. Thus, it requires a set of proposals to encourage entrepreneurship among students.
\end{abstract}

\section{Keywords: ENTREPRENEUR, MEXICO}

\section{INTRODUCTION}

Economic growth in Mexico and the world indicates that, with few exceptions, there is a low rate of increase in the economic activity. In a globalized world, circulation of production factors takes to looking for enterprises efficiency, competitiveness and productivity, the previous, in an innovation and knowledge creation ambiance as the present source of richness generation. Thus generated effects of diverse nature of society, one of these effects is in the employment line, which increase leads to improving the welfare of the population. Economic theory explains the known positive relationship between economic growth and job creation. In addition to address the structural problem of the lack of these, also it must cope with the growth of layoffs and higher unemployment rate in general, without leaving out the attention of situations as the precariousness of employment and the informal economy as well as technological change that replaces force of labour by capital. 
Over the past 3 decades, Mexico records on average a low rate of growth in the number of new enterprises and the vast majority of those generated every year close their doors before the two years, reason why, the backlog of jobs increases with the passage of time. The percentage of the population economically active (EAP) vacant or in conditions of underemployment does not descend, there is also a segment of the EAP that is located in underemployment (not to mention those who are working in the informal economy). Given this scenario, the generation and consolidation of enterprises at the national level has become an issue in the political, economic and social agenda of Mexico.

Traditionally, it has been considered large enterprises as the main generator of employment, given its operation size, infrastructure and their requirements of production factors; however, they are not the main employers. Therefore, in medium, small and microenterprises are real options of major employments generation, part of it is found in the opening and operation of new entrepreneurial-driven companies. They have the qualities or characteristics that lead them to conceive and carry out new projects, which result in opening business. Nevertheless, a first difficulty arises, it is thought that those one with new ideas to bring out possess the capacities and abilities to realize them. The reality is that few times is presented this combination of entrepreneurs with entrepreneurship.

In Mexico, entrepreneurial profile is configured as a young adult between 25 and 44 years old, mainly higher education with a median income. Mostly, entrepreneurs decide to incite activities by opportunity to increase their incomes or obtain major independence. The major part of startups and new enterprises are in services sector oriented to consumer, followed by transformation sector (Global Entrepreneurship Monitor, 2013).

This working paper aims to determine entrepreneur profile students of Bachelor of the UAEM Tenancingo University Center and its change over time. Consequently, are identified the entrepreneur's features consisting in values, abilities and capacities. It should be noted that the University campus is located in a rural region (economic base are the production of flowers and services).

\section{BACKGROUND}

Programs of support or business promotion by Governments as well as educational institutions, presuppose the presence of qualities or characteristics of entrepreneur in the general population as well as an enabling environment. According to Espíritu and Sastre (2007b) will reach to consider that profile or entrepreneurship, innovation and risk-taking has implied.

The individual identified by his entrepreneurial skill conceives innovative and viable projects, materializes them and establishes the conditions that ensure the survival and improvement of his idea. Consequently, entrepreneurship involves a number of attributes: imagination and creativity; being interested in a situation and have aspirations for change and the willingness to invest the energy it requires, perseverance to not abandon the project when difficulties arise, leadership to motivate, guide people involved in the project, knowledge to identify what that is feasible and what is not, and the leadership and ability to take risks (Galán and Pedro, 1994 and Rusque, et al., 1998 cited in Ramírez 2010).

The presence of entrepreneurs in an economy has positive effects on this one, among which are: a) the positive impact of entrepreneurs and SMEs (small and medium enterprises) on economic growth and job creation, b) compared with developed economies as United States, in many regions of the world is presented low entrepreneurial dynamism (Guzmán and Romero, 2006).

Among the various proposals to study entrepreneurs, its context and its effects is the model of the GEM (Global Entrepreneurship Monitor). This is responsible for characterizing the entrepreneurial activity to assess three major dimensions: attitudes, activity and aspirations of 
entrepreneurship. Attitudes are the first dimension and focus to the degree in which the people of a country have a tendency to appreciate entrepreneurship, to recognize opportunities and to assess themselves the skills and knowledge to undertake, as well as the fear of failure that could stand as an impediment to it. Secondly, entrepreneurship, dimension in which is measured the entrepreneurs' involvement at different stages of the entrepreneurial process; also considering whether the decision to undertake is motivated by the need or opportunity. Thirdly, there are the entrepreneurial aspirations, which evaluate the expectation of job creation, internationalization and innovation that entrepreneurs seek to develop their business initiatives, it configures important elements in the economic development of the country (Global Entrepreneurship Monitor, 2013).

In addition to supporting the economic growth of a locality, region or country, it is considered that entrepreneurs are the engines of economic development of each country, especially in developing countries, thus opening new business creates jobs, expands markets and leads to prosperity (Zaczkowska and Cuc, 2011).

Henrekson and Sanandaji (2013) cited in Global Entrepreneurship Monitor (2013) indicate that the real impact of entrepreneurship in economic development is entrepreneurs who create, develop and expand corporate-type companies and to concentrate measurement of entrepreneurship in the self-employment and small businesses, the Schumpeterian approach is left out, in which it emphasizes the innovative entrepreneur (who performed "disruptive" activities in the market) or replicator entrepreneur (who replicates/mimics other small businesses).

Meanwhile, Fuentes and Sanchez (2010) understand the businessman (entrepreneur) as a determinant of innovation and progress in the economic system. Further, they indicate that the entrepreneur has been studied based on three dimensions: his demographic profile, his psychological profile and his sociological profile. Therefore, the entrepreneur has been approached from various social sciences and with different approaches.

The model of personality traits and propensity to create companies Shane (2003) and Hernangómez et al. (2005) cited by Fuentes and Sanchez (2010) shows a series of relationships between the individual attributes that affect the expected value of the opportunity, therefore, the probability that the individual is released to exploit it. Psychological and non-psychological factors are separated. Both types of features have been particularly relevant in explaining the existence of entrepreneurial attitudes and motivations. Among the main non-psychological factors are outstanding the demographic characteristics, variables of training and experience. Demographic characteristics excel in strategic decision making; training and experience are considered increasingly important as success factors.

Based on these psychological and non-psychological factors it is possible to establish a number of analytical elements consisting of theoretical approaches. According to Espíritu and Sastre, (2007a) and (2007b) cited in Ramírez (2010), the most prominent theories that relate to entrepreneurship and the entrepreneurs are: a) role theory, b) incubator, c) values toward work, d) of personality traits, and e) the institutional theory.

First, role theory, points as the employer's conduct is influenced by the social network part and especially of those who compose his family. Incubator theory refers to the influence of work experience in the decision to create a new business or the ability to detect opportunities. For its part, the theory of values has been an important issue in cross-cultural psychology and has been used as variables to understand the attitudes and behaviors among different groups and social categories. The basic structure used universal mentioned requirements and consists of ten types of values. In addition, the theory of personality traits emphasizes that the most entrepreneurial people differ in characteristics or traits that make them different from the rest. Finally, institutional theory provides a consistent and adequate conceptual framework within the 
theories that defend the idea that are the institutions those ones which influence business creation and business function.

There are diverse approaches from different disciplines dealing with the study, therefore, there is no single way to determine or measure the presence of profile or entrepreneurship. In this context, Espíritu (2011) suggests that it is possible to display the basic role of the entrepreneur in society if personal traits that define him are known, the behaviors are based on skills or abilities that are learned, and the necessary knowledge through institutional supports are possible to acquire but not psychological traits. Espíritu and Sastre (2007a and 2007b) and Fuentes and Sanchez (2010) propose an analytical variable called entrepreneurship. Based on Brazeal and Krueger (1994) quoted in Fuentes and Sánchez (2010) model of entrepreneurial potential arises.

First, they use two basic dimensions of entrepreneurial intentions, "perception of viability" and "perception of desirability." Also they employ a third dimension called "self-help" both in terms of time and money you are willing to invest in the project. In fourth place, there is a dimension, which refers to the "detection skills" to discover "business opportunities". Thus, they propose a number of hypotheses about the causes or determinants that lead a person to be an entrepreneur, in other words, make a profile of entrepreneurship. The arguments expressed in hypotheses are:

Hypothesis 1. The existence of family businesses or self-employed in the life of college students, will positively influence their entrepreneurship.

Hypothesis 2. Prior experience of previous work will positively influence the entrepreneurial attitude of college students.

Hypothesis 3. Students who show a high degree of superior value for self-transcend will have greater opportunities to develop their own business.

Hypothesis 4. Students who show a high degree of higher conservation value, will have greater possibilities of starting their own business.

Hypothesis 5. Students who show a higher degree of value to higher-order openness to change, have a greater chance of starting their own business.

Hypothesis 6. Students who have a high score in the value of higher order selfaggrandizement, are more likely to start their own business.

Hypothesis 7. The personality trait of kindness will positively influence the entrepreneurial attitude of college students.

Hypothesis 8. The personality trait need for achievement, will positively influence the entrepreneurial attitude of college students.

Hypothesis 9. The personality trait risk appetite will positively influence the entrepreneurial attitude of college students.

Hypothesis 10 . The personality trait extraversion will positively influence the intentions of students to start their own business.

Hypothesis 11. The personality trait tolerance for ambiguity will positively influence the entrepreneurial attitude of college students.

Hypothesis 12. The personality trait internal control will positively influence the entrepreneurial attitude of college students.

Hypothesis 13. Neuroticism (having a degree of neurosis) will negatively influence the attitude of students towards entrepreneurship.

Hypothesis 14. The education received by students in business will positively influence the intention of creating their own business.

Hypothesis 15. The participation of university students in the field and courses on entrepreneurship will positively influence their entrepreneurial intention. 
Meanwhile, it is also possible to define the action of undertake, in concept and action, is very close to manage in the sense of completion (devise, develop mentally), gestate (start, develop, opinions, attitudes, feelings). As process has a great similarity to the administrative cycle, with emphasis on planning, organization and direction. Undertaking is a result of the interaction between structure and behavior. The importance of entrepreneurship is most evident in complex, dynamic environments in which both, individuals and organizations need to imagine alternatives to face situations for which there are not similar previous experiences. The challenges are new and innovative responses also are required (Rusque, et al., 1998 cited in Ramírez, 2010). Therefore, they regard as relevant the following variables to define an entrepreneur:

1. Creativity and innovation as a way of occupying the intelligence to see reality surpassing individual locks and offering different personal responses.

2. Tenacity: as an active force to obstacles, resistance to obstacles.

3. Self-confidence, and sense of self-esteem, security that comes from the awareness that one has for himself.

4. Leadership and coordination: as ability to mobilize resources and exchange of information for functional operation.

5. Communication: as forms of exchange of information between actors humanly integrated and stimulants

6. Negotiation and ability to reach agreements.

7. Responsibility: as a commitment to compliance.

8. Ability to take risk and the ability to take uncertainty, venturing to new and different things.

9. Altruism and solidarity, projection to others, individually transcendence.

10. Honesty: as transparency, clarity of purpose.

\section{METHODOLOGY}

The study is exploratory; therefore, their sources of information are primary. For collecting information it is used a stratified sample of students from each degree. Based on Ramírez (2010), sampling is expressed in the following research sheet:

Technical details of the investigation
Geographical scope: Local: Centro Universitario UAEM Tenancingo, Universidad
Autónoma del Estado de México (UAEM Tenancingo University Center, Autonomous
University of the State of Mexico)
Population universe: Students of Bachelor of the UAEM Tenancingo University Center
Size of the universe: 757 students
Method of application: Survey through structured questionnaire
Sampling method: Stratified sampling by degree
Sample size: 100 valid surveys
Sampling fraction: $7.57 \%$
Error: $\pm 5 \%$
Confidence level: $90 \%$
Date: March-May 2014

Source: Own elaboration

The content of the questionnaire consists of 24 questions whose theme is referring to those suggested by Espíritu and Sastre (2007a and 2007b), which in turn can identify 8 of the 10 
features mentioned by Rusque, et al. (1998). A scale of responses arranged in order of frequency, from never (1.0) to always (5.0) was established. Once the information is obtained, a descriptive analysis to denote key entrepreneurial characteristics of students was done.

\section{ANALYSIS OF RESULTS}

The results of the survey are presented in table 1 . The issues related to the characteristic profile or entrepreneurial spirit that correspond to the questions asked in the survey. Two columns that represent the results of the sample applied in this study and those obtained by Ramírez (2010), in order to compare the situation and above all, the changes occurred between the two dates.

Table 1

Entrepreneurial characteristics of students of the University Center UAEM Tenancingo

\begin{tabular}{|c|l|c|c|}
\hline Number & \multicolumn{1}{|c|}{ Features profile or entrepreneurship } & $\begin{array}{c}\text { Global students CU } \\
\text { UAEM Tenancingo } \\
\text { 2010 year }\end{array}$ & $\begin{array}{c}\text { Global students CU } \\
\text { UAEM Tenancingo } \\
\text { today }\end{array}$ \\
\hline 1 & Business family atmosphere & 3.4 & 3.6 \\
\hline 2 & Previous work experience & 3.8 & 3.8 \\
\hline 3 & Personal transcendence & 3.7 & 3.8 \\
\hline 4 & Conservation of person or group & 3.2 & 3.5 \\
\hline 5 & Openness to change & 4.1 & 3.9 \\
\hline 6 & Personal growth & 4.0 & 3.6 \\
\hline 7 & Friendliness & 4.2 & 4.1 \\
\hline 8 & Tenacity & 4.5 & 3.1 \\
\hline 9 & Take risks & 3.5 & 3.9 \\
\hline 10 & Being extroverted & & \\
\hline
\end{tabular}

Table 1 continuation

\begin{tabular}{|c|l|c|c|}
\hline Number & \multicolumn{1}{|c|}{ Features profile or entrepreneurship } & $\begin{array}{c}\text { Global students CU } \\
\text { UAEM Tenancingo } \\
\text { 2010 year }\end{array}$ & $\begin{array}{c}\text { Global students CU } \\
\text { UAEM Tenancingo } \\
\text { current time }\end{array}$ \\
\hline 11 & Tolerance for ambiguity & 3.3 & 3.7 \\
\hline 12 & Self control & 3.9 & 3.7 \\
\hline 13 & Being apprehensive & 2.2 & 2.5 \\
\hline 14 & Degree with courses in entrepreneurship & 3.8 & 3.7 \\
\hline 15 & Proactive problem solving & 3.4 & 3.8
\end{tabular}




\begin{tabular}{|c|l|c|c|}
\hline 16 & Confronting obstacles & 3.9 & 3.8 \\
\hline 17 & Personal dignity rating & 4.3 & 3.8 \\
\hline 18 & Group Leadership Initiative & 3.6 & 3.6 \\
\hline 19 & Proper communication & 3.3 & 3.6 \\
\hline 20 & Proper negotiation & 3.4 & 3.8 \\
\hline 21 & Group Leadership & 3.8 & 3.9 \\
\hline 22 & Handle risk and uncertainty & 3,9 & 3.7 \\
\hline 23 & Willingness to help solve problems & 4.0 & 3.7 \\
\hline 24 & Statement of truth & 3.5 & 3.6 \\
\hline
\end{tabular}

Source: Own elaboration. The 2010 information corresponds to Ramírez (2010) and current information corresponds to the present investigation.

Note that in 2010 it was worked with the four open degrees at that time, for the present research five degrees were covered, gastronomy is the one incorporated. In each subject, the averages are shown. For all questions, except question 13, it is expected that the closer to 5.0 the student has that quality, value or capacity, while closer to 1.0 is devoid of having entrepreneurial profile. In question 13, a value close to 5.0 is negative and close to 1.0 is positive for the trait of an entrepreneur.

The analysis of the traits of an entrepreneur employs a criterion which serves to locate. This criterion describes the presence or possession of a given feature is near 5 values is considered high, values between 2 and 4 is moderate and values less than 2 does not have this feature. Thus, we can identify three possible situations: the strong presence, moderate (ambiguous) and the low presence (or absence).

The set of qualities, values or traits shows that students have a high presence of traits in 2 of the 24 studied areas, the rest has different levels of moderation, without a low or zero level in any field. That is, students have high presence in $8.3 \%$ of features of entrepreneurship.

Currently, profile or entrepreneurial spirit of a undergraduate student is characterized by: 1) Consider that being friendly is important for customer service (customers). Kindness is a positive element that performs efficient communication.

2) Keep in mind reaching goals. Tenacity is a trait that can overcome obstacles, despite them; it is possible to achieve the goals. Significantly, it is the appearance of a higher score on.

However, in comparison with Ramírez (2010), only these two features are preserved and a change occurs in five features' situation. The features that are no longer markedly: openness to change, the search for personal growth (enlargement) attitude to take risks, responsiveness in situations that call into question the value of the person and be willing to help their peers with situations to resolve or coping problems. So they become moderate traits in students. Note that the rest of the characteristics of entrepreneur are moderately possessed, therefore, students are in a position to undertake (but would be encouraged).

In the comparison over time, traits that reduce their presence, in addition to those who move from strong to moderate, are: self-control, overcome obstacles, degree with entrepreneurial courses and handle risk and uncertainty.

Meanwhile, the traits that show an increase in their presence are the rest, except for two that are unchanged: previous work experience and initiative of leading groups.

\section{CONCLUSIONS}


There is no single way to understand and explain to entrepreneurs, therefore, research on the analysis of personal traits and the immediate environment of people to indicate the degree of presence of entrepreneurship was delimited. The most relevant features in the present study are less marked than before, that is, has moderated the entrepreneurial profile and strengthened over time. Since the number of strong features decreased but the number of characteristics that increased their score increased.

To trigger the entrepreneurial profile among students, encouragement and promotion actions for carrying out projects are needed, thereby, strengthening the moderate profile for go higher. For example, Ministry of Economy, Ministry of Education, Culture and Sports and Coca Cola Spain Foundation (n/d) indicate certain values that should have an entrepreneur, therefore, businesses and governments should promote. From a personal level are creativity, autonomy, self-confidence, tenacity, sense of responsibility, ability to take the risk, meanwhile, in the social sphere they are leadership, team spirit and solidarity.

\section{REFERENCES}

Espíritu, R., \& Sastre, M. (2007a) Factores explicativos sobre la actitud emprendedora de los estudiantes universitarios de la Comunidad de Madrid. Mimeo, Universidad Complutense de Madrid, 32.

Espíritu, R., \& Sastre, M. (2007b) La actitud emprendedora durante la vida académica de los estudiantes universitarios, Cuadernos de Estudios Empresariales, (17), 95-116.

Espíritu, R. (2011) Análisis de la intención emprendedora en estudiantes universitarios a través de rasgos de personalidad, Multiciencias, 11(1), 65-75.

Fuentes, F., \& Sánchez, S. (2010) Análisis del perfil emprendedor: Una perspectiva de género, Estudios de Economía Aplicada, 28(3), 1-28.

Global Entrepreneurship Monitor (2013) Monitor Global de Actividad Emprendedora México 2013. México, GEM.

Guzmán, J. \& Romero, L., (2006) La política europea de fomento empresarial en Galindo, M. A. y Fernández, J. (coordinadores) (2006). Política socioeconómica en la Unión Europea, Madrid, Delta Publicaciones.

Ministerio de Economía, Ministerio de Educación, Cultura y Deportes y Fundación Coca Cola España (n. d.) El espiritu emprendedor motor del futuro. Madrid, Ministerio de Economía / Ministerio de Educación, Cultura y Deportes / Fundación Coca Cola España.

Ramírez, J. (2010) ¿Los estudiantes universitarios del sur del Estado de México tienen espíritu emprendedor que contribuye al desarrollo económico? Anales de Economía Aplicada 2010, Madrid: ASEPELT Delta Editores.

Rusque, A. et al. (1998) Medición de capacidad emprendedora de estudiantes de escuelas de administración de Europa y América Latina. Ponencia presentada en "XII Congreso Latinoamericano sobre espíritu empresarial ”, evento realizado por el Instituto Tecnológico de Costa Rica, en San José de Costa Rica, 9-11 de noviembre, 20.

Zaczkowska, E., \& Cuc, J. (2011) Formación emprendedora desde la perspectiva del estudiante, ECO Revista Académica, Economía, empresarialidad y desarrollo, edición especial 6, agosto, 113-121. 